\title{
A Study on Accounting Risks and Countermeasures for Financial Institutions
}

\author{
Xu Jie ${ }^{1}$ Su Weidong ${ }^{2}$ \\ ${ }^{1}$ School of Business \\ Qilu University of Technology Jinan, China \\ ${ }^{2}$ School of Finance \\ Qilu University of Technology Jinan, China
}

\begin{abstract}
As the rapid development of financial institutions and constant deepening of financial system reform in China, financial institutions are facing a growing number of risks. Whether China's national economy grows healthy and sustainable is determined by the development of financial institutions' accounting .Only when we take effective measures to mitigate these risks, financial institutions can play their part in market economy. This paper discusses the forms of accounting risks for financial institutions in China and presents effective precautionary measures further, which helps financial institutions to find a way to avoid risks and then promote healthy development of financial institutions.
\end{abstract}

Keywords: Accounting risks Financial institutions Measures

\section{Introduction}

Financial institutions accounting refers to an information system. It applies the accounting principle to financial institutions, reflecting financial institutions' economic activities and providing financial condition, operating results and cash flows. Financial accounting is one of the most important aspects of financial institutions' internal management; therefore the accounting method has its own characteristics.

Accounting risks for financial institutions are resulting from the subjective mistakes and objective condition changes of financial institutions in the process of operation and management, then makes financial institutions property and reputation loss. Along with the development of commodity and currency economy, finance has become the core of modern economy, financial institutions play an important role in China's economic development in the market economic system .It is of great significance for the normal operation and development of the whole national economic system. Accounting risks for financial institutions may influence the financial industry, even the entire social economy. Thus it is necessary for researchers to investigate forms and countermeasures of financial institutions' accounting risks. And the current difficult problem that financial firms need to solve is how to take effective measures to prevent possible risks and achieve their function in the market economy system.

\section{Forms of accounting risks for financial institutions}

China's financial institutions' accounting risks are mainly in the following areas: accounting exposure, bills payment and 
settlement risk, accounting supervision risk, accounting operational risk and internal control risk.

\subsection{Accounting exposure}

Accounting is the basic function of financial institutions' accounting. If the improper accounting methods or nonstandard accounting procedures are used in the accounting, then accounting quality will be low. It is easier to have risks of the financial institutions. In the real work, some financial institutions gloss over the financial statements to safeguard their own interests in violation of the requirements of monetary policy, resulting untrue information and providing false financial statements, thus increase the possibility of risks to a certain extant.

\subsection{Bills payment and settlement risk}

Bills payment and settlement risk is caused by fraud of some criminals used in the bills payment and settlement process. Financial officers may not strictly audit the settlement documents and conduct business transaction in accordance with the provisions, which make criminals take advantage of the flaw and misappropriated of settlement documents, resulting risks or losses on financial institutions accounting.

\subsection{Accounting supervision risk}

Accounting supervision is an important function of accounting of financial institutions. The rationalization and legalizing of operating activities can be promoted by accounting supervision. At present, the weakness supervision of financial institutions' accounting would not achieve the role of accounting supervision, and it is mainly limited by the business philosophy. For some unreasonable or illegal business transaction, the accounting department is generally unable to supervise efficiently while the business risk of loss often companied with a chain reaction.

\subsection{Accounting operational risk}

Accounting of financial institutions, as a professional industry with strong risks, is easier to make great losses of assets when facing a large number of settlement bills or cash. In the present, some criminals regard bank as its main target, any one case of the crime will be more or less involved in the accounting operating department, once the accounting department decreased control and reduced the level of accounting, the green light will be opened for criminals and increased operational risk.

\subsection{Internal control risk}

With the continuous deepening of reform of financial system, the existing internal control system for financial institutions has been guided by the past internal control management approach, financial institutions can not be timely promulgated of new and standardized accounting internal control system, thus financial institutions accounting internal control system lags behind the financial institutions development. Financial accounting internal control system exists in name only, making financial business unsystematic. There are many defects in accounting internal control system, for example, imperfect internal control system, soundless constraint mechanisms, as well as the lack of key part of accounting internal control system.

\section{Effective precautionary measures of accounting risks for financial institutions}

The financial institutions' accounting risk prevention system is a sub-system of financial risks preventing system; it occupies an important position in the accounting system. 


\subsection{Improve financial institutions' accounting personnel quality and integrity, strengthen their risk prevention consciousness.}

One of the important factors of guarding against the financial institutions' accounting risk is the financial institutions accounting personnel's risk consciousness. Due to the spring up of financial institutions, more and more accounting personnel join in accounting work in a short period of time, leading to low quality of accounting personnel and shortage of high quality accounting personnel. First, we need to strengthen the construction of ideological and moral quality, making accounting personnel fully understand work's important function in risk prevention. Second, we also need to carry on the accounting personnel training, improving operation level and ability of staffs. It is necessary to conduct irregular assessment and evaluation casually. Finally, place those who love accounting work and have serious attitude into important position to prevent arise of risks.

\subsection{Improve financial institutions accounting system further.}

In today's globalization environment, in accordance with internationally accepted accounting standards carefully, we should improve financial institutions' accounting system, which is not only the need of China's financial industry to adapt to the international standard but also effective to prevent risks of financial institutions accounting and enhance competitiveness of financial institutions. In China, although the turnover tax and income tax have been cut down, the tax burden is still high. Therefore, financial institutions need to reduce the tax burden level further; second, financial institutions accounting should fully consider the financial innovation and the trend of development of new financial business, develop new financial business relevant accounting standards and norms, making the financial institutions guard against financial risks better.

\subsection{Strengthen function of financial supervision and management accounting.}

First, strengthen communication and coordination of supervising subject of the accounting of financial institutions. Internal audit department and social supervision department of financial institutions should conduct the work of supervising so that supervision department may exactly know financial accounting and effectively prevent various risks in time, avoiding reiteration of effort. Second, the financial supervision and accounting work include not only advanced supervision but also process and afterwards regulation. From the internal supervision of financial institutions, the key to strengthen supervision beforehand is "cabinet system" function. Process regulation may stress on the checking of accounting. To set up a series of accounting internal control evaluation system, which conforms to the characteristics of financial accounting and meets the needs of development of accounting of financial institutions? It is necessary to improve collection, collation, analysis and early warning system of financial accounting information.

\subsection{Establish effective risk warning mechanism.}

When we are stressed to change the simple post-supervision into beforehand and comprehensive control approaches, it is essential to establish risk warning mechanism. Also in accounting work, we'd better set up a series of effective index system, reflecting the possible problems through the daily accounting so that bank decision-making departments 
may promptly take targeted measures and achieve the purpose of avoiding risk.

\subsection{Develop modern accounting methods.}

With the development of science and technology, accounting has transformed the traditional manual accounting to computer accounting. The switch has a positive influence. First, according to the requirements of the financial institutions accounting, researchers may develop corresponding financial software, helping simplify the work of financial institutions accounting. Application of accounting computerization may strengthen the standardization of the accounting and reduce the corresponding error, this is not foolproof. If just rely on the accounting computerization, greater risks may be caused. Supervision is very important, therefore, to regularly check for processing business, find risk timely an correspond treatment measures.

\section{Conclusion}

In the process of China's financial reform and development, although it is impossible to completely avoid the accounting risks for financial institutions, as long as we attach great importance to prevent risks of financial institutions accounting work and strengthen the research and analysis of the nature of accounting risks for financial institutions, we may find the sticking point of formation of risks and take effective measures to prevent risks. Rising of the level of preventing accounting risks for financial institutions will reduce financial accounting so as to further strengthen the financial accounting basis, promoting China's financial reform and development to continuously progress.

\section{ACKNOWLEGEMENT}

This work has been funded by Humanities and Social Science Foundation of Ministry of Education of China (12YJA630102).

\section{Reference}

[1] Guo Li. "The financial accounting risk analysis of the manifestation and the preventive measures," Proc. Of China Township Institutions Accounting, 2011.

[2] Ren Meijer. "Commercial bank accounting risk prevention extraction,"Proc. Of Chinese Business, 2011.

[3] Liu Ling. "Financial accounting risk prevention and control," Proc. Of Modern Economic Information, 2010.

[4] You Hongyan. "Reflections on the risk of financial accounting," Proc. Of Private Science and Technology, 2011.

[5] Li Hongwei. “Accounting risks for financial institutions and its prevention measures," Proc. Of Reform\&Openning, 2012. 